\title{
Hereditary persistence of fetal hemoglobin-sickle cell disease syndrome
}

INSERM

\section{Source}

INSERM. (1999). Orphanet: an online rare disease and orphan drug data base. Hereditary persistence of fetal hemoglobin-sickle cell disease syndrome. ORPHA:251380

A rare, genetic, hemog lobinopathy characterized by generally mild clinical phenotype, high fetal hemoglobin levels and mild microcytosis and hypochromia. In some cases, acute sickle cell disease manifestations were reported, namely acute chest syndrome and acute pain crisis. 